\title{
Quaderni
}

QUADERN I Communication, technologies, pouvoir

\section{Making sense of innovation: from weapon to instrument to buzzword}

Pour une histoire du concept d'innovation : arme, instrument et cliché

\section{Benoît Godin}

\section{(2) OpenEdition}

12 Journals

\section{Electronic version}

URL: http://journals.openedition.org/quaderni/977

DOI: 10.4000/quaderni.977

ISSN: 2105-2956

\section{Publisher}

Les éditions de la Maison des sciences de l'Homme

\section{Printed version}

Date of publication: 5 May 2016

Number of pages: $21-40$

\section{Electronic reference}

Benoît Godin, « Making sense of innovation: from weapon to instrument to buzzword », Quaderni [Online], 90 | Printemps 2016, Online since 05 May 2018, connection on 19 April 2019. URL : http:// journals.openedition.org/quaderni/977; DOI : 10.4000/quaderni.977 


\section{$D$ ossier}

\section{Making sense of innovation:} from weapon to
instrument to buzzword

Benoît

Godin

Professor

Institut National de la Recherche Scientifique (Montreal, Canada)
There are words and concepts - many words and concepts - that we use with no knowledge of their past. Such concepts are taken for granted and their meaning is rarely questioned. Innovation is such an anonymous concept.

Today, the concept of innovation is wedded to an economic ideology, so much that we forget that it has mainly been a political - and contested concept for the last five hundred years. Before the twentieth century, innovation was a vice, something explicitly forbidden by law and used as a linguistic weapon by the opponents of change. Innovation had nothing to do with creativity, not yet. And there was no theory of innovation. The concept has a "negative history", to use Pierre Rosanvallon's phrase on the history of democracy (Rosanvallon, 2003: 43-45): a history of contestations, refutations, denials and denigrations. Innovation is something that the opponent of change or the conservative calls innovation. In contrast, today innovation is a word of honor. Everyone likes to be called an innovator; every firm innovates (or does it?); governments legislate to make whole nations innovative. As John Lyons says of the imagination: innovation "is popularly considered to be a great endowment. People, and even institutions, are criticized for [not being innovative enough]" (Lyons, 2005: x).

How could people of the previous centuries constantly innovate but at the same time deny they innovate? In what follows, I suggest that the paradox, as David Zaret calls it (Zaret, 2000: $37-43$; 254-57), is best explained linguistically. Innovation is a bad word and people prefer to cast their innovative behavior using other words. "Il fallait que l'innovation", claimed the 
French historian and intellectual Edgar Quintet, "s'accomplît sans que le génie du passé eût le moindre soupçon qu'il entrât quelque chose de nouveau dans le monde" [Innovation had to be carried out without the geniuses from previous times having the least suspicion that something new was being brought into the world] (Quintet, 1865 : 208). "What people claim to be doing and how they justify it", suggests John Pocock, "is just as revealing as what they finally do" (Pocock, 1985: 218).

Through what route has the concept changed meaning, when and why? This occurred gradually over two hundred years. Innovation acquired a positive connotation because of its instrumental function to political, social and material progress of societies (Godin, 2015). From the early nineteenth century, a whole vocabulary developed that tells a story that "create, even sanctify", to use Gordon Schochet's words on the history of political thought (Schochet, 1993: 322), a progressive future, rehabilitating dirty words until then - revolution - and adding new ones creativity - to talk of and about innovation. From that time on, innovation became a catchword that everyone understood spontaneously - or thought he understood -; that every theorist talked about; that every government espoused (Table 1).

The history of the concept of innovation is an untold story. It is a story of myths and conceptual confusions. Many attribute the origin of the concept to economics and to Joseph Schumpeter (e.g. Staudenmaier, 1985: 56; Alter, 2000: 8). Some historians of classical times mix and do not distinguish novelty, which was accepted to several extents, and innovation, which is political and contested, as does Armand d'Angour in his history of novelty in Ancient Greece (Angour, 2011). Pocock, for his part, attributes a typology of innovators to Nicollo Machiavelli, whereas the author of The Prince is concerned with change and how different types of rulers react to change (Pocock, 1975). Still others pretend that there was no innovation in the past, in spite of discourses

Table 1 : Frequency of the Term Innovation Over Time (Google Ngram)

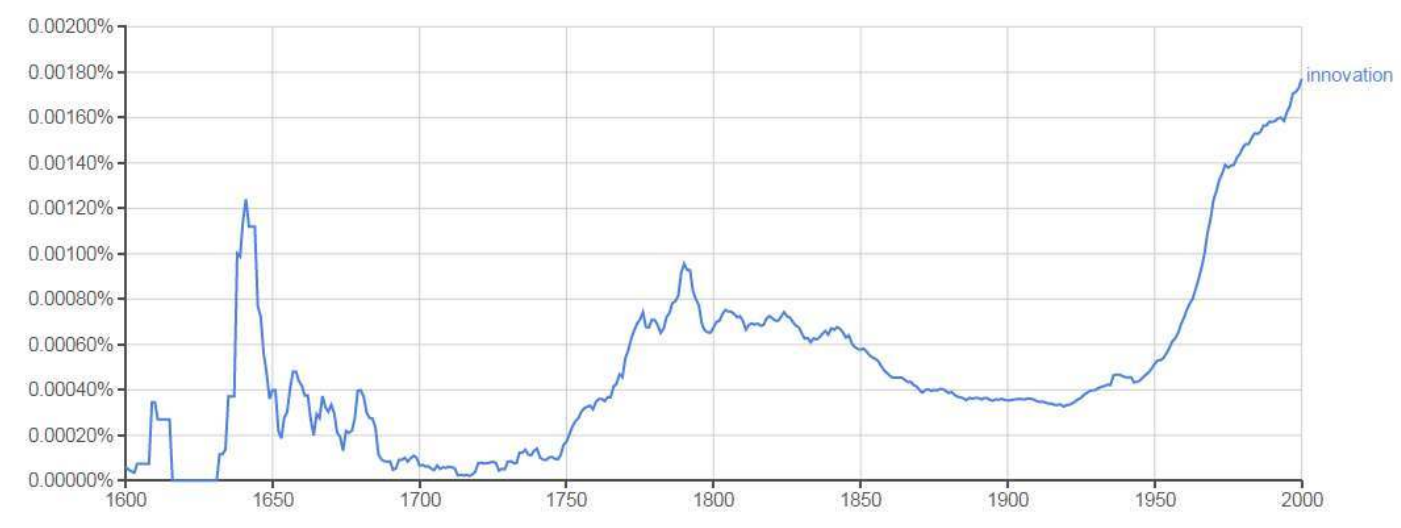


on innovation as such. To Anthony Milton, the innovation the English puritans accused the bishops of in the seventeenth century is not real innovation because it was symbolic or minor, as we say today (Milton, 1995) - a myopia shared centuries ago by, at least, Jacques Bossuet (Bossuet, 1751). Milton forgets that innovation is a subjective concept. Anachronism is also omnipresent in modern writings. For example, some pretend that the concept "social innovation", as a counter-concept to technological innovation, is quite recent (Cloutier, 2003), while in fact it appeared one hundred years before the phrase "technological innovation". To continue: in many translations of old texts, there is regular language inflation on the concept of innovation, perhaps because of a context which denigrates (or praises) innovation. ' Finally, on the entry 'innovation', etymological dictionaries start in the fourteenth century, ignoring sources from ancient times.

In this paper, I will study the ways in which thoughts on innovation of early-modern society gave rise to innovation theory in the twentieth century, namely how, when and why a pejorative and morally connoted word shifted to a much valued concept. I offer a history of the concept of innovation, going back to Antiquity, a history that takes the use of the concept seriously: from polemical to instrumental to theoretical.

\section{Prehistory}

From its very emergence in Ancient Greece, the concept of innovation (kainotomia) had a political connotation. As "introducing change into the established order", innovation was subversive, or revolutionary, as we say today. Such were
Plato's and Aristotle's meanings; one focusing on cultural innovation (games, music) and its effect on society, ${ }^{2}$ the other on changes to political constitutions. ${ }^{3}$ Certainly, there were a few positive uses of the concept in classical Greece. Xenophon on 'political economy' is one example (Xenophon, Ways and Means). Xenophon's use of kainotomia is literal. The word is a combination of kainos (new) and the radical tom (cut; cutting). Xenophon's use of innovation is "making new cuttings", namely opening new mine galleries later writers (Plato, Aristotle) used the concept in a metaphorical sense (making new). Xenophon's objective was to increase the revenues of the city of Athens. Plutarch and his biography of Greeks and Romans is another example of positive uses of the concept (Plutarch, Lives). Mention needs to be made to Polybius too. In his Histories, Polybius coins kainopoein, the meaning of which is "making new", a term that he applies to himself as inventor of a new kind of history. But in general, innovation is negative. In general too, innovation is a word with few occurrences among ancient writers.

The political and contested connotation survived, or rather was revived during the Reformation (see below). In the meantime, the concept made its entry into Latin vocabulary, with a positive meaning. In contrast to the Greeks, the Romans had no word for innovation, although they had many words for novelty (novitas, res nova). In addition, the verb novare carried a pejorative meaning similar to kainotomia/mein, depending on the context. Yet, from the fourth century, Latin writers, first of all Christian writers and poets, coined in-novo, which means renewing (return to the original or pure soul), in line with other 
Christian terms of the time - rebirth, regeneration, reformation (Ladner, 1959) - and according to the message of the New Testament (God sent his son Jesus to save man from $\sin$ ). Innovo has no future connotation as such, although it brings a 'new order'. Innovo refers to the past: going back to purity or the original soul. The Vulgate was influential here. In 382, Pope Damasus I commissioned Saint Jerome to produce a 'standard' version of the Vetus Latina, which he did using original Greek and Hebrew texts. Four books in the Vulgate make use of innovo in a spiritual context (Job, Lamentations, Psalms, Wisdom).

Revolution and renewing are the two poles of a spectrum of meanings that define innovation in the following centuries, both in dictionaries and lay discourses - contrary to political thought, there was no theoretical work on innovation before the late nineteenth century. Renewing points to the past (return to the old, changing or renewing the old) and revolution points to the future (introducing something new, entirely new). For example, Catholic Popes in the fifteenth century used innovation in a legal context as renewing previous statutes, and Machiavelli did so in the sense of imitation. In spite of his 'revolutionary' political morality, Machiavelli's meaning of innovation was introducing new laws similar to those of great rulers in the past. On the other hand, reformers and counter-reformers from the sixteenth century used the concept as a word of accusation for changing things with 'revolutionary' consequences impending.

\section{Innovation and Order}

Innovation thus began with both a positive and negative meaning, but subsequently lost this valence when it moved to the politico-religious sphere of the Reformation. From the very beginning of the Reformation, royal and ecclesiastical authorities started using innovation in discourse. In 1548, Edward VI, King of England and successor to Henry VIII, issued a Proclamation Against Those That Doeth Innouate. The proclamation places innovation in context, constitutes an admonition not to innovate and imposes punishments on offenders (England and Wales. Sovereign. Edward VI, 1548):

The proclamation was followed by the Book of Common Prayer, whose preface enjoins people not to meddle with the "folly" and "innovations and new-fangledness" of some men (Church of England, 1549). A hundred years later, King Charles prohibited innovation again (England and Wales. Sovereign. Charles I, 1641), and the Church produced lists of forbidden innovations (Church of England, 1641), required bishops to visit parishes to enforce the ban, instructed bishops and archbishops as well as doctors (universities) and school-masters to take an oath against innovations and ordered trials to prosecute the "innovators" (Church of Scotland, 1707). Advice books and treatises for princes and courtiers supported this understanding, and included instructions not to innovate. Books of manners urged people not to meddle with innovation. Speeches and sermons spoke against innovation, religious and political. Every opponent to innovation puritans, ecclesiasts, royalists and pamphleteers - regularly repeated the admonitions of monarchs in support of their own case against innovators - until the second half of the nineteenth century in the case of religion. 
The Reformation was a key moment in the history of the concept of innovation. At a time when the Reformation was incomplete and still in the making, the Catholics accused the reformers of innovating. The Puritans served the same argument to the Protestant Church, accused of bringing the Church back to Catholicism. The word served both sides of the debate: reformers and counter-reformers. It was precisely in the context of the Reformation that the concept entered everyday discourse. The English puritan Henry Burton was an emblematic writer. Every later argument on innovation would be found in the pamphlet For God and the King (1636), the sum (with additions and enhancements) of two sermons preached on November 5 "to teach [his] people obedience to both" God and the King in these times of "innovations tending to reduce us to that Religion of Rome". Innovators were those who transgressed the disciplinary order and intend to change it for evil purposes, namely bringing the Protestant Church back to Catholic doctrine and discipline. Innovating is a private liberty - as heresy is - that creeps imperceptibly and, with time, leads to dangerous consequences. ${ }^{5}$ Archbishop William Laud and his supporters (Peter Heylin, Christopher Dow) produced replies that opposed Burton's argument entirely: "We are not innovating" but bringing the Church back to purity. Burton was brought to the Court, put into prison and had his ears cut off.

This was only the beginning. Soon the meaning of innovation was to be enlarged. First, to the political. The monarchists of the seventeenth and eighteenth centuries accused the republicans of being "innovators". Such was the accusation made against Henry Neville in England and his pamphlet Plato Redivivus: or, a Dialogue Concerning Government (1681). Innovation is revolutionary and violent. No republican - no citizen in fact, even the most famous Protestant reformers or the French revolutionaries - thought of applying the concept to his own project. Innovation is too bad a word for this. In contrast, and precisely because the word is morally connoted, the monarchists used and abused the word and labelled the Republican as an innovator (Anonymous, 1681; Goddard, 1684). This linguistic practice continued until the French Revolution - and later -, and casted a general disrepute on the idea of innovation. As François-Dominique de Reynaud Montlosier puts it on the disgust of novelty [dégoût des nouveautés]: "Un préjugé général, produit par la haine de la révolution, a établi, avec des apparences assez favorables, que tout ce qui l'a immédiatement précédé, est excellent: c'est comme innovation qu'on la dénigre principalement; et par là même un discrédit général a dî s'attacher à toutes sortes d'innovations" [A general bias, arising from the hatred toward the revolution, established, with apparently considerable support, that everything immediately preceding it was excellent: it is as an innovation that is denigrated; and as a result every innovation has come to be discredited] (Montlosier, 1814, tome trois: 137).

Secondly, innovation widened its meaning to the social. The social reformer or socialist of the nineteenth century is called a "social innovator", as William Sargant puts it in Social Innovators and Their Scheme (1858). His aim is to overthrow the social order, namely private property. Innovation is a scheme or design in a pejorative sense - as it is a conspiracy in political literature (words used 
are project or plan or plot or machination). This connotation remained in vocabulary until late in the nineteenth century - although some writers discuss social innovation using the positive idea of (social) reform. For example, in 1888, a popular edition of the Encyclopedia Britannica included a long article on communism which begins as follows: "Communism is the name given to the schemes of social innovation which have for their starting point the attempted overthrow of the institution of private property" (Encyclopedia Britannica, 1888: 211).

Everyone shares this representation of innovation. Natural philosophers, from Francis Bacon onward, never refer to innovation as what is certainly the most innovative project in science: the experimental method (Godin, 2014a). Equally, very few artisans and inventors talk of their invention in terms of innovation (Godin, Forthcoming). Innovation is political.

\section{Innovation and Progress}

The concept of revolution and the concept of innovation changed meaning and start to be used in a positive sense at about the same time. The "spirit of innovation", a pejorative phrase of the previous centuries, became one of praise. This occurred gradually over the nineteenth century, particularly in France - "le centre de l'esprit philosophique et novateur" [the centre of philosophical and innovative spirit] (Littré, 1873: 208) -, and got full hearing in the twentieth century. Two rehabilitations of the concept serve the purpose. One, a semantic re-description: People start producing reflexive thoughts on what innovation is and conclude that the concept admits of diffe- rent interpretations. Innovation is neutral. There are good and bad innovations. But in practice innovation is a word of accusation, the "war cry of the fools", as Jean d'Alembert puts it in his Éloge de L'Abbé François Régnier Desmarais (1786), a "damned word", as the fourierist Victor Considérant claims (Considérant, 1834: 312). Yet, innovation may be a good thing, namely useful. As the philosopher Jeremy Bentham puts it in The Book of Fallacies (Bentham, 1824: 143-44, 218):

"Innovation means a bad change, presenting to the mind, besides the idea of a change, the proposition, either that change in general is a bad thing, or at least that the sort of change in question is a bad change... [But] to say all new things are bad, is as much as to say all things are bad, or, at any event, at their commencement; for of all the old things ever seen or heard of, there is not one that was not once new. Whatever is now establishment was once innovation... The idea of novelty was the only idea originally attached to the term innovation, and the only one which is directly expressed in the etymology."

Here lies a second rehabilitation, an instrumental one. Innovation is a means to political, social and material progress. "If it had not been for this happy spirit of innovation, what would be the state of mechanics, mathematics, geography, astronomy, and all the useful arts and sciences" (Pigott, 1792: 171). Such is a repeated statement after the French Revolution.

The "Government of the Church by bishops is an innovation"; the British constitution "owes its beauty to innovation"; "the great charter and the bill of rights are innovations"; "the office of 
the speaker and the freedom of speech" are too. Writers narrate or rather rewrite the story of the past in terms of innovation, including the Reformation and the Revolution (e.g. Montlosier, 1814; Blanc, 1847; Quintet, 1865; Dubeuf, 1866) and talk of innovators in superlative terms (Patterson, 1850). Innovation is a source of national pride too (Touchard-Lafosse and Roberge, 1822-24; Delepierre, 1836; Candolle, 1873):

Writers also discuss the feelings of the people towards innovation. For example, 'anthropologists' look at how the "primitives" react to innovation, as opposed to the moderns (e.g. Gobineau, 1853). The dichotomy tradition-innovation /conservateur-novateur becomes a common framework for understanding the past, the present and the future.

Yet the transition from the negative to the positive is not sudden. First, the neutral use of the concept coexisted with the pejorative before the nineteenth century (e.g. Saint Simon, 1713). Second, the pejorative use of innovation continued to share a place with the positive over the nineteenth century (e.g. Winslow, 1835; Littledale, 1868). One had to wait until the twentieth century for a complete reversal in the representation of innovation. This occurred after World War II. Those who contested innovation in the past governments - start de-contesting innovation and produce reflexive thoughts on innovation as a policy tool. ${ }^{6}$ One after the other, international organizations and governments embrace innovation as a solution to economic problems and international competitiveness (OECD, 1966; 1969; 1970; 1971; US Department of Commerce, 1967: UK Advisory Council on Science and Technology, 1968), and then launch innovation policies (Pavitt and Walker, 1976).

At that precise moment, the dominant representation of innovation shifts to that of the economy: technological innovation - a phrase that emerged after World War II $^{7}$ - as commercialized invention. Technological innovation serves economic growth. It is a tool to reduce lags or gaps in productivity between countries and is conductive to industrial leadership. A whole new set of arguments develops: research and development (R\&D) leads to innovation and innovation to prosperity (Kuznets, 1959; Pavitt, 1963). ${ }^{8}$ Statistics are developed to support the idea: innovation surveys are administered to firms and the numbers collected into "innovation scoreboards" that serve as so-called evidence-based information to policy-makers. Innovation becomes a basic concept of economic policy. In a matter of decades, science policy shifts to technology policy to innovation policy, and indicators on science and technology are relabeled indicators of innovation. In all these efforts, the governments are supported by the academics as consultants, who imagine models of innovation by the dozens, as a way to frame and guide policies. Model itself becomes an integral concept in the literature on innovation.

\section{Theorizing Innovation}

Early in the twentieth century, innovation became a common word and began to appear in law, education, literature, arts, sciences, medicine and the social sciences. Innovation is cast in terms of a vocabulary of initiative, ${ }^{9}$ together with entrepreneurship and creativity. Two discourses encapsulate all this in a story that is essential to 
innovation as a phenomenon: a public (government) discourse (see above) and a theoretical discourse. The theorists began to study innovation and, in doing so, embrace a eulogistic view of innovation, or "pro-innovation bias", as the sociologist Everett Rogers puts it. The aim is to understand innovation in order to serve the practical: how to accelerate and get more out of innovation; what kind of strategy and policy are required to this end.

Beginning in the 1940s, theoretical thoughts on innovation appeared and theories of innovation multiply afterwards. Psychological, sociological and economically-oriented theories followed one after the other: Gabriel Tarde (1890) and Schumpeter (1939), economic historians (Maclaurin, 1949), anthropologists (Barnett, 1953), sociologists (Rogers, 1962; Coleman et al., 1966; Langrish et al., 1972), education (Miles, 1964; Carlson, 1965), politics (Thompson, 1969), management (Carter and William, 1958; Burns and Stalker, 1961; Argyris, 1965; Myers and Marquis, 1969; Zaltman et al., 1973; Twiss, 1974), engineers (Morton, 1971), mainstream economists (Mansfield, 1968; Mansfield et al., 1971) and evolutionary economists (Freeman, 1974; Nelson and Winter, 1977). What was called change (e.g. social change) and modernization before becomes innovation. Everyone is now considered an innovator, from the individual to organizations to nations. Innovation is "any thought, behavior, or thing that is new because it is qualitatively different from existing forms", suggests the anthropologist Homer Barnett, in one of the very first theories of innovation in the twentieth century (Barnett, 1953: 7). To the sociologist Everett Rogers, an influential theorist of innovation, innovation is "an idea perceived as new by an individual" (Rogers, 1962: 13) "or other unit of adoption" (Rogers, 1983: 11). A totally new representation of innovation develops:

- Innovation is no longer seen as subversive to the social order, but simply opposed to traditional ways of doing things.

- The innovator is not a heretic. He is simply different from the masses or from his fellows. He may be a deviant, but in a sociological sense: an original, a marginal, a nonconformist, unorthodox.

- The innovator is ingenious and creative. He is an experimenter, an entrepreneur, a leader; he is the agent of change.

Two theoretical perspectives particularly - economics (technology) and policy - serve a new ideology, and the theorists rapidly got a government hearing. To paraphrase Kevin Sharpe on revolutions (Sharpe, 2000: 6-7), the study of innovation - particularly the management, policy and economics of innovation (Godin, 2012, 2014b) - established a cultural dominance which contributed to political discourses. These disciplines are part of the political culture that was essential to its ascendency and was instrumental in its creation and survival.

A new semantic field develops for a new society. In the previous centuries, the semantic field of innovation was composed of four concepts. One is change, which is accepted depending on the context, but innovation is not. Innovation (as well as alteration) is intentional change, as contrasted to change which is natural or the doing of God. Among the intentional changes, reformation (and 
renovation) is accepted. As Burke puts it: "As in most questions of state, there is a middle. There is something else than the mere alternative of absolute destruction, or unreformed existence" (Burke, 1790: 158). "To innovate is not to reform" (Burke, 1796: 290). Reformation is gradual. It builds on what already exist. Reformation acts here as a counter-concept to innovation..$^{10} \mathrm{~A}$ third concept of the then semantic field of innovation is revolution. A revolution is radical, violent and total. By the nineteenth century, innovation had encapsulated this later connotation. Innovation is change to the established order, a change that is intentional, a change that brings radical change or revolutionarily transforms society.

The semantic field of the twentieth century is different. To be sure, some terms were in place in the previous centuries, such as change. Today, innovation is intentional change in the sense of planned change. It necessitates strategy and investment. Reformation also gave a key term of the modern vocabulary: reform. Innovation retains the idea of revolution too. There are major innovations, so it is said, and they are the most studied innovations because of their revolutionary impacts on society, so it is believed. In spite of these continuities, a new vocabulary has emerged. Innovation is originality, in three senses. First, innovation is difference, departure. ${ }^{11}$ Second, innovation is creativity in the sense of combination. Innovation recombines ideas or things in a new way (Barnett, 1953). Third, innovation refers to origin, namely being first to originate (initiate) or use a new practice. For example, to economists, innovators are the firsts to commercialize a new invention. This connotation owes its existence to the market ideology. As David Teece explains, "innovating firms often fail to obtain significant economic returns from an innovation while customers, imitators and other industry participants benefit" (Teece, 1986: 285). As a consequence, theories of innovation are concerned with ways of preventing imitation or "keeping imitators/ followers at bay" (Teece, 1986: 290), that is, how can firms get the full benefit of their innovation, how the "innovator is to avoid handing over the lion's share of the profits to imitators" (Teece, 1986: 292). Teece discusses the "strategies the firm must follow to maximize its share of industry profits relative to imitators and other competitors" (Teece, 1986: 300-301).

Such as is the case for economists, to sociologists, innovation is the first adoption of a new practice, in the present case a new practice in a group or a community, but includes a far larger range of practices than the economists suggest although the majority of sociologists also focus on technology. This meaning owes to governmental institutions' objective of modernizing agriculture and diffusing new farm techniques among farmers (Subcommittee on the Diffusion and Adoption of Farm Practices, 1952). It gave rise to a whole vocabulary on innovators versus laggards (Rogers, 1962). Both the sociologists' and economists' vocabulary encapsulates the fundamental representation of innovation of the twentieth century. Innovation is source or revolutionary change (terms used are major, structural, systemic, paradigmatic), hence the need to support innovators (change agents, entrepreneurs) and make everyone an innovator (the laggards). To Machiavelli, "All human affairs are ever in a state of flux and cannot stand still", hence the need for (political) innovations to stabilize the 
world (The Prince, I, 6; see also The Discourses, II, Preface). In contrast, to the moderns, the world is too stable and needs revolutionary innovations.

Originality is only one basic concept of the semantic field of innovation. There are also counter-concepts. One is imitation. Innovation is contrasted to imitation. Imitation is not original or creative, so it is said. When discussing the strategies of firms, Chris Freeman, a mainstream theorist on technological innovation, limits and contrasts "the traditional strategy [use of invention as] essentially non-innovative, or insofar as it is innovative it is restricted [my italics] to the adoption of process innovations, generated elsewhere but available equally to all firms in the industry" (Freeman, 1974: 257). To Freeman and his colleagues, innovation "excludes simple imitation or 'adoption' by imitators" (SPRU, 1972: 7). Such a view is contested. To a few others, like Charles Carter and Bruce Williams, a firm "may be highly progressive [innovative] without showing much trace of originality [research]. It may simply copy what is done elsewhere ... It is nonsense to identify progressiveness with inventiveness" (Carter and Williams, 1958: 108). As the anthropologist Barnett puts it, the imitator does something new "instead of doing what he is accustomed to do" (Barnett, 1961: 34). ${ }^{12}$

Another counter-concept to innovation is invention. Innovation is contrasted to invention, which is mental. Innovation is putting invention to work. As Schumpeter, among others, puts it: "innovation is possible without anything we should identify as invention and invention does not necessarily induce innovation" (Schumpeter, 1939: 84-85). Yet, invention plays the role of a basic concept to innovation at the same time. While science and innovation were two separated things to natural philosophers of past centuries, they are now part of the same process. Invention is the first step in the process of innovation. Innovation starts with basic research, then applied research then development. This view gave rise to what is known as the "linear model of innovation", a much criticized view but one that remains in the background of policies and theories (Godin, 2006; 2008).

However, the most basic concept of the semantic field is 'action' or action-related concepts. According to theorists, innovation is:

- Introduction: introducing something new to the world. This concept first appeared among anthropologists and sociologists, but is most popular among economists and management.

- Application, assimilation, transformation, exploitation, translation, implementation: applying (new) knowledge in a practical context. Innovation is the application of ideas, inventions and science.

- Adoption, acceptance, utilization, diffusion: adopting a new behaviour or practice. These concepts are mainly used by sociologists.

- Commercialization: bringing a new good to the market. Used concurrently with introduction or application, this concept applies to industrial innovation.

Action goes hand in hand with another concept, usefulness/utility, talked about in terms of:

- Progress, modernization, advancement, development; 
- (Economic) growth, productivity, competitiveness, profits;

- (Organizational) efficiency;

- (Social) needs.

Innovation is no longer an individual affair but a collective process. To be sure, the twentieth century has its individual heroes: the entrepreneurs. Yet, entrepreneurs are only one part of the process of innovation: a total process as some call it, or a socioeconomic process. As Jack Morton, Engineer and Research Director at Bell Laboratories, who brought the transistor from invention to market, and who is the author of numerous articles and a book on innovation, suggests (Morton, 1968: 57):

"Innovation is not a single action but a total [my italics] process of interrelated parts. It is not just the discovery of new knowledge, not just the development of a new product, manufacturing technique, or service, nor the creation of a new market. Rather, it is all [my italics] these things: a process in which all of these creative acts, from research to service, are present, acting together in an integrated way toward a common goal."

Defining innovation as a process is a twentieth century 'innovation'. Herein lies a semantic 'innovation', an 'innovation' that has had a major impact on the modern representation of innovation. Until then, innovation as a concept was either a substantive (something new) or a verb (introducing, adopting something new), an end or a means. Sometimes it is also discussed in terms of a faculty (combination, creativity), an attitude (radicalism) or aptitude (skill) or quality (originality, departure, difference):
- Substantive: novelties (new ideas, behaviours, objects)

- Action: introducing (or bringing in) something new

- Process: a sequence of activities from generating ideas to their use in practice

From the mid-twentieth century, innovation has been studied as a chronological "process", a sequential process in time (Maclaurin, 1949; Subcommittee on the Diffusion and Adoption of Farm Practices, 1952). Innovation is not a thing or a single act but a series of events or activities (called stages) with a purpose. The theorists have made themselves "innovative ideologists" here, to use Quentin Skinner's phrase (Skinner, 2002a; $2002 b)$. They brought in a new definition of innovation, in reaction to earlier ones. The nuance between innovation as a verb and innovation as a process is not as clear-cut as it might appear at first sight. This is not unlike innovation as substantive or verb. In fact, innovation is an abstract word that admits of two meanings: action (introduction of something new) and result/ outcome (the new). For example, sociologists use innovation as a substantive but focus on the verb (diffusion). Similarly, economists stress the verb form (commercialization). Be that as it may, innovation as a process has contributed to giving the concept of innovation a very large function: innovation encompasses every dimension of an invention, from generation (initiation) to diffusion. To the sociologists, the "conversion process", to use Brian Twiss' phrase (Twiss, 1974), is one from (individual) adoption to (social) diffusion; to the economists, from invention to commercialization; to management schools from (product) development to manufacturing. 
Everywhere, this process is framed in terms of a sequence (with stages) called models.

Innovation is a counter-concept to science - and more particularly to basic research - as a dominant cultural value of the twentieth century. Technological innovation sprang from a tension between science (for its own sake) and society, or aspiration to action. It emerged as a category in the twentieth century because in discourse, action and policy, it was useful to include a large(r) number of people (than scientists) and activities (than science or basic research). Innovation is a process that includes several people and activities, so it is claimed. Science or research is only one step or factor in the process of innovation, and often not even a necessary step.

\section{Conclusion}

There is a complete lack of historical work on the concept of innovation in literature: hence the current myths on the origin of the concept - unanimously attributed to Schumpeter; hence innovation as the object of a spontaneous and dominant representation - innovation as technological innovation; hence the absence of reflexivity - innovation is always good.

As the nineteenth century ended, the word innovation had accumulated four characteristics that made of it a powerful (and pejorative) term. From the Greeks, the representation of innovation had retained its subversive (revolutionary) character. The Reformation added a heretic dimension (individual liberty), and the Renaissance a violent overtone. Together, these characteristics led to a fourth one: innovation is conspiracy (designs, schemes, plots). Yet in spite of these connotations that made a word (innovation) part of the vocabulary and discourses, innovation seems to have escaped the attention of intellectual or conceptual historians. Many concepts of change (crisis, revolution, progress, modernity) have been studied in literature, but innovation has not.

The changing fortune of innovation over the centuries sheds light on the values of a time. In the seventeenth and eighteenth centuries, the uses of the concept were essentially polemical. It served as a linguistic weapon, attaching a pejorative label to the innovators. To the ruling classes, the concept of innovation serves to discipline people and regulate society. To writers and pamphleteers, innovation is a word used to exploit emotions, to insult and, as many other words do, make "the enemy odious or contemptible by asserting he was like somebody or something we already disliked or looked down on" (Lewis, 1960: 323). In Studies in Words, Clive Staples Lewis speaks of a "tendency to select our pejorative epithets with a view not to their accuracy but to their power of hurting... not to inform... but to annoy" (Lewis, 1960: 326). A "word is selected solely because the speaker thought it was the one that the enemy (if he could hear it) would most dislike... The purpose of all opprobrious language is, not to describe, but to hurt... We call the enemy not what we think he is but what we think he would least like to be called" (Lewis, 1960: 122).

In contrast, from the nineteenth century onward, innovation started to refer to a central value of modern times: progress and utility. As a consequence, many people started appropriating the concept for their own ends. These developments 
led to the transformation of the concept from a means to an end to an end in itself. Some words, Lewis suggests again, have nothing but a halo, a "mystique by which a whole society lives" (Lewis, 1960: 282). The word seeps into almost every sentence. Over the twentieth century, innovation has become quite a valuable buzzword, a magic word. Innovation is the panacea to every socioeconomic problem. One need not inquire into the society's problems. Innovation is the $a$ priori solution.

\section{$R \cdot \dot{E} \cdot F \cdot E \cdot R \cdot E \cdot N \cdot C \cdot E \cdot S$}

ALEMBERT, Jean le Rond d' (1786), Histoire des membres de l'Académie française, morts depuis 1700 jusqu'en 1771, pour servir de suite aux éloges imprimés \& lus dans les Séances publiques de cette Compagnie, tome 3, Amsterdam: Moutard.

ALTER, Norbert (2000), L'innovation ordinaire, Paris: PUF.

ANGOUR, Armand d' (2011), The Greeks and the New: Novelty in Ancient Greek Imagination and Experience, Cambridge: Cambridge University Press.

ANONYMOUS (W.W.) (1681), Antidotum Britannicum: or, a counter-pest against the Destructive Principles of Plato Redivivus..., against ALL INNOVATORS, London: Richard Sare.

ARGYRIS, Chris (1965), Organization and Innovation, Homewood (Ill.): Irwin.

BARNETT, Homer G. (1953), Innovation: the Basis of Cultural Change, New York: McGraw Hill.

BARNETT, Homer G. (1961), "The Innovative Process", in Alfred L. Kroeber: A Memorial, The Kroeber Anthropological Society Papers, 25: 25-42.

BENTHAM, Jeremy (1824), The Book of Fallacies: from Unfinished Papers of Jeremy Bentham, London: John and H. L. Hunt.

BLANC, Louis (1847), Histoire de la Révolution française, Paris : Librairie internationale, Lacroix et Cie, 1878.

BOSSUET, Jacques Bénigne (1751), Opuscules de M. Bossuet, évêque de Meaux, tome 5, Paris: Le Mercier; Dessaint \& Saillant; Jean-Th. Herissant; Durand; Le Prieur. 
BURKE, Edmund (1790), Reflections on the Revolution in France, New York: Dover, 2006. BURKE, Edmund (1796), "A Letter to a Noble Lord”, in Daniel E. Ritchie (ed.), Burke, Edmund. Further Reflections on the Revolution in France, Liberty Fund, Indianapolis (Indiana), 1991.

BURNS, Tom and George Macpherson STALKER (1961), The Management of Innovation, London: Tavistock Publication.

BURTON, Henry (1636), For God and the King, Amsterdam: Theatrum Orbis Terrarum; Norwood (NJ): W. J. Johnson, 1976.

BUSH, Vannevar (1945), Science: The Endless Frontier, United States Government Printing Office, Washington.

CANDOLlE, Alphonse de (1873), Histoire des sciences et des savants depuis deux siècles, d'après l'opinion des principales académies ou sociétés scientifiques, Genève : II Georg.

CARLSON, Richard O. (1965), Adoption of Educational Innovations, Eugene: Center for Advanced Study of Educational Administration, University Of Oregon.

CARTER, Charles F. and Bruce R. WILLIAMS (1958), Investment in Innovation, London: Oxford University Press.

CHURCH OF ENGLAND (1549), The booke of common prayer and administracion of the Sacramentes, and other rites of the Church: after the use of the Church of England, London: in officinal Edouardi Whitchurche [and Nicolas Hill] Cum privilegio ad imprimendum solum.

CHURCH OF ENGLAND (1641), A copie of the proceedings of some worthy and learned divines, appointed by the Lords to meet at the Bishop of Lincolnes in Westminster touching innovations in the doctrine and discipline of the Church of England. Together with considerations upon the
Common prayer book, London: no editor. CHURCH OF SCOTLAND (1707), Act of the Commission of the General Assembly, Against Innovations in the Worship of God, Edinburgh: no editor.

CLOUTIER, Julie (2003), Qu'est-ce que l'innovation sociale?, Montreal, UQAM: Crises.

COMTE, Auguste (1839), Cours de philosophie positive, tome quatrième, Paris: Bachelier.

COLEMAN, James S., Elihu KATZ and Herbert MENZEL (1966), Medical Innovation: A Diffusion Study, Indianapolis: Bobbs-Merrill.

CONSIDÉRANT, Victor (1834), Destinée sociale, Volume I, Paris: Librairies du Palais-Royal. DELEPIERRE, Octave (1836), Aperçu historique et raisonné des découvertes, inventions, innovations et perfectionnements, en Belgique, dans les sciences, les arts, l'industrie, etc. depuis les Romains, Bruges: Félix de Pachtere.

DUBEUF, Jean-Marie (1866), Revue rétrospective des principaux faits, innovations et événements acquis à l'histoire depuis le règne de Napoléon III, Caen: Emile Alliot et Co.

ENCYCLOPEDIA BRITANNICA (1888), Communism, T. S. Baynes (ed.), volume 6, Third edition, New York: Henry G. Allen: 211-19. ENGELL, James (1981), The Creative Imagination: Enlightenment to Romanticism, Cambridge (Mass.): Harvard University Press.

ENGLAND AND WALES. SOVEREIGN (Edward VI) (1548), A proclamation against those that doeth innouate, alter or leaue doune any rite or ceremonie in the Church, of their priuate aucthoritie: and against them which preacheth without licence, set furth the .vj. daie of Februarij, in the seconde yere of the Kynges Maiesties most gracious reigne, Excusum Londini: In aedibus Richardi Graftoni regij impressoris. Cum priuilegio 
ad imprimendum solum.

ENGLAND AND WALES. SOVEREIGN (Charles I) (1641), The King's Proclamation on Religion, in S. R. Gardiner (ed.), The Constitutional Documents of the Puritan Revolution, 1625-1660, Oxford: Clarendon Press, 1906.

ENGLAND AND WALES. SOVEREIGN (Elizabeth I) (1602), By the Queene a proclamation for proceeding against Iesuites and secular priests, their receiuers, relieuers, and maintainers, London: Robert Barker.

FREEDEN, Michael (1996), Ideologies and Political Theory: A Conceptual Approach, Oxford: Clarendon Press.

FREEMAN, Chris (1974), The Economics of Industrial Innovation, Harmondsworth: Penguin Books.

GOBINEAU, Arthur, comte de (1853), Essai sur l'inégalité des races, Paris: Pierre Belfond [1967].

GODDARD, Thomas (1684), Plato's Demon: or, the State-Physician Unmaskt; Being a Discourse in Answer to a Book call'd Plato Redivivus, London, H. Hill.

GODIN, Benoît (2006), "The Linear Model of Innovation: The Historical Construction of an Analytical Framework", Science, Technology, and Human Values, 31 (6): 639-67.

GODIN, Benoît (2008), "In the Shadow of Schumpeter: W. Rupert Maclaurin and the Study of Technological Innovation", Minerva 46 (3): 343-360.

GODIN, Benoît (2012), “Innovation Studies: The Invention of a Specialty”, Minerva, 50 (4): 397-421.

GODIN, Benoît (2014a), Innovation and Science: When Science Had Nothing to Do with Innovation, and Vice-Versa, Project on the Intellectual
History of Innovation, Working Paper no. 16, Montreal: INRS.

GODIN, Benoît (2014b), "Innovation Studies: Staking the Claim for a New Disciplinary “Tribe"”, Minerva, 52 (4): 489-495.

GODIN, Benoît (2015), Innovation Contested: The Idea of Innovation Over the Centuries, London: Routledge.

GODIN, Benoît (Forthcoming), “Technological Innovation: On the Origin and Development of an Elusive Concept", Technology and Culture, Forthcoming.

KOSELLECK, Reinhart (1975), The HistoricalPolitical Semantics of Asymmetrical Counter Concepts, in R. Koselleck (ed.), Futures Past: On the Semantics of Historical Time, New York: Columbia University Press, 2004: 155-91.

KUZNETS, Simon (1959), Six Lectures on Economic Growth, Glencoe (Ill.): Free Press.

LADNER, Gerhart B. (1959), The Idea of Reform: Its Impact on Christian Thought and Action in the Age of the Fathers, Cambridge (Mass.): Harvard University Press.

LANGRISH, John, Michael GIBBONS, W. G. EVANS and F. R. JEVONS (1972), Wealth from Knowledge: Studies of Innovation in Industry, London: Macmillan.

LEWIS, Clive Staples (1960), Studies in Words, Cambridge: Cambridge University Press, 1967. LITTLEDALE, Richard Frederick (1868), Innovations: a Lecture Delivered in the Assembly Rooms, Liverpool, April 23rd, 1868, Oxford:

A. R. Mowbray; London: Simpkin, Marschall \& Co.

LITTRÉ, Émile (1873), La science au point de vue philosophique, Paris Didier et Cie.

LYONS, John D. (2005), Before Imagination:

Embodied Thought from Montaigne to Rousseau, 
Stanford: (CA): Stanford University Press. MACLAURIN, William Rupert (1949), Invention and Innovation in the Radio Industry, New York: Macmillan.

MANSFIELD, Edwin (1968), Industrial Research and Technological Innovation: An Econometric Analysis, New York: W.W. Norton.

MANSFIELD, Edwin, John RAPOPORT, Jerome SCHNEE, Samuel WAGNER and Michael HAMBURGER (1971), Research and Innovation in the Modern Corporation, New York: Norton. MILES, Matthew B. (ed.) (1964), Innovation in Education, New York: Columbia University Press.

MILTON, Anthony (1995), Catholic and Reformed: The Roman and Protestant Churches in English Protestant Thought, 1600-1640, Cambridge: Cambridge University Press.

MONTLOSIER, François Dominique de Reynaud de (1814), De la monarchie française, depuis son établissement jusqu'à nos jours; ou recherches sur les anciennes institutions françaises, leur progrès, leur décadence, et sur les causes qui ont amené la révolution et ses diverses phases jusqu'à la déclaration d'empire; avec un supplément sur le gouvernement de Buonaparte, depuis ses comencemens jusqu'à sa chute; et sur le retour de la maison de Bourbon, Three volumes, Paris: H. Nicolle/A. Édron/Gide fils.

MORTON, Jack A. (1968), "The Innovation of Innovation”, IEEE Transactions on Engineering Management, EM-15 (2): 57-65.

MORTON, Jack A. (1971), Organizing for Innovation: A Systems Approach to Technical Management, New York: McGraw Hill.

MYERS, Sumner and Donald G. MARQUIS (1969), Successful Industrial Innovations: A Study of Factors Underlying Innovation in Se- lected Firms, NSF 69-17, Washington: National Science Foundation.

NELSON, Richard R. and Sidney G. WINTER (1977), "In Search of a Useful Theory of Innovation", Research Policy, 6: 36-76.

NEVILLE, Henry (1681), Plato redivivus, or, A dialogue concerning government wherein, by observations drawn from other kingdoms and states both ancient and modern, an endeavour is used to discover the present politick distemper of our own, with the causes and remedies... Second edition, London: Printed for S.I. and sold by R. Dew. NORVAL, Aletta J. (2000), “The Things We Do with Words: Contemporary Approaches to the Analysis of Ideology", British Journal of Political Science, 30: 313-46.

OECD (1966), Government and Technical Innovation, Paris: OECD.

OECD (1969), The Management of Innovation in Education, Center for Educational Research and Innovation (CERI), Paris: OECD.

OECD (1970), Gaps in Technology: Comparisons between Countries in Education, R\&D, Technological Innovation, International Economic Exchanges, Paris: OECD.

OECD (1971), The Conditions for Success in Technological Innovation, Keith Pavitt and C. Wald, Paris: OECD.

PATTERSON, John (1850), Innovation Entitled to a Full and Candid Hearing, New York: Fowlers and Wells.

PAVITT, Keith (1963), "Research, Innovation and Economic Growth”, Nature, 200 (4903), 19 October: 206-10.

PAVITT, Keith, and W. Walker (1976), “Government Policies towards Industrial Innovation: A Review", Research Policy, 5: 11-97.

PIGOTT, Charles (1792), The Jockey Club or a 
Sketch of the Manners of the Age, London: M. D. Symons, Paternoster-Row.

POCOCK, John G. A. (1975), The Machiavellian Moment: Florentine Political Thought and the Atlantic Republican Tradition, Princeton: Princeton University Press.

POCOCK, John G. A. (1985), "Introduction: The State of the Art”, in J. G. A. Pocock (ed.), Virtue, Commerce, and History, Cambridge, Cambridge University Press: 1-34.

QUINET, Edgar (1865), La Révolution, Paris: Félix Alcan, 1891.

ROGERS, Everett M. (1962), The Diffusion of Innovation, New York: Free Press.

ROSENVALlON, Pierre (2003), Pour une histoire conceptuelle du politique, Paris: Seuil. SAINT-SIMON, Louis de Rouvroy, duc de (1713), Mémoires, tome 11, Paris: Hachette [1872].

SARGANT, William L. (1858), Social Innovators and Their Schemes, London: Smith, Elder and Co. SCHOCHET, Gordon J. (1993), "Why Should History Matter? Political Theory and the History of Discourse", in J. G. A. Pocock (ed.), The Varieties of British Political Thought, 1500-1800, Cambridge: Cambridge University Press: 321-57. SCHUMPETER, Joseph A. (1939), Business Cycles: A Theoretical, Historical, and Statistical Analysis of the Capitalist Process, Volume 1, New York: McGraw Hill.

SHARPE, Kevin M. (2000), Reading Revolutions: The Politics of Reading in Early Modern England, New Haven and London: Yale University Press.

SKINNER, Quentin (2002a), "Classical Liberty, Renaissance Translation and the English Civil War", in Q. SKINNER (ed.), Visions of Politics, Volume 2, Cambridge: Cambridge University
Press: 308-43.

SKINNER, Quentin (2002b), "Moral Principles and Social Change", in Q. Skinner (ed.), Visions of Politics: Regarding Method, Volume 1, Cambridge, Cambridge University Press: 145-57.

SPRU (1972), Success and Failure in Industrial Innovation: A Summary of Project SAPPHO, London: Centre for the Study of Industrial Innovation.

STAUDENMAIER, John M. (1985), Technology's Storytellers: Reweaving the Human Fabric, Cambridge (Mass.): MIT Press.

STERN, Bernhard J. (1937), "Resistance to the Adoption of Technological Innovations", in US National Resources Committee, Technological Trends and National Policy, Subcommittee on Technology, Washington: USGPO: 39-66.

SUBCOMMITTEE on the Diffusion and Adoption of Farm Practices (1952), Sociological Research on the Diffusion and Adoption of New Farm Practices: A Review of Previous Research and a Statement of Hypotheses and Needed Research, a report from the Rural Sociological Society, Lexington (Kentuky): Kentuky Agricultural Experimental Station and Department of Rural Sociology, University of Kentuky.

TARDE, Gabriel (1890), Les lois de l'imitation, Paris: Les empêcheurs de penser en rond, 2001. TEECE, David J. (1986), "Profiting from Technological Innovation: Implications for Integration, Collaboration, Licensing and Public Policy", Research Policy, 15: 285-305.

THOMPSON, Victor Alexander (1969), Bureaucracy and Innovation, Alabama: University of Alabama Press.

TOCQUEVILLE, Alexis de (1835), De la démocratie en Amérique I, Paris: Gallimard, 1992. TOUCHARD-LAFOSSE, George, and François 
ROBERGE (1822-24), Dictionnaire chronologique et raisonné des découvertes, inventions, innovations, perfectionnements, observations nouvelles et importations, en France, dans les sciences, la littérature, les arts, l'agriculture, le commerce et l'industrie, de 1789 à la fin de 1820, Paris: Louis Colas.

TWISS, Brian C. (1974), Managing Technological Innovation, London: Longman.

UK ADVISORY COUNCIL FOR SCIENCE AND TECHNOLOGY (1968), Technological Innovation in Britain, London: HMSO. US DEPARTMENT OF COMMERCE (1967), Technological Innovation: Its Environment and Management, Washington: USGPO.

VEBLEN, Thorstein (1915), Imperial Germany and the Industrial Revolution, New York: Macmillan.

WINSLOW, Hubbard (1835), The Dangerous Tendency to Innovations and Extremes in Education, Delivered Before the American Institute of Instruction, Boston: Tuttle and Weeks.

ZALTMAN, Gerald, Robert DUNCAN and Jonny HOLBEK (1973), Innovations and Organizations, New York: John Wiley.

ZARET, David (2000), Origins of Democratic Culture: Printing, Petitions, and the Public Sphere in Early-Modern England, Princeton (NJ): Princeton University Press.

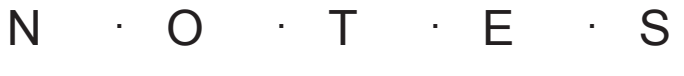

1. For example, while Francesco Guicciardini's Storia d'Italia (1568) contains only one occurrence of innouare, one finds dozens of occurrences in English translations, like that of Geffray Fenton published in 1579.

2. "When the programme of games is prescribed and secures that the same children always play the same games and delight in the same toys in the same way and under the same conditions, it allows the real and serious laws also to remain undisturbed; but when these games vary and suffer innovations... [children] have no fixed and acknowledged standard of propriety and impropriety" (Plato, The Laws, VII, 797b).

3. "Even a small thing may cause changes. If for example people abandon some small feature of their constitution, next time they will with an easier mind tamper with some other and slightly more important feature, until in the end they tamper with the whole structure ... The whole set up of the constitution [is] altered and it passed into the hands of the power-group that had started the process of innovation" [neoterizein] (Aristotle, Politics, X, xii, 1316b).

4. $I n$ is a prefix that expresses action: a movement towards something.

5. This chain reaction or slippery slope argument goes back to Plato, Aristotle and Polybius. It was served regularly against innovators, from the Reformation onward. "All Innovations in Government are Dangerous", writes an anonymous writer against the English republican Henry Neville. It is "like a Watch, of which any one piece lost will disorder the whole" (Anonymous, 1681: 172).

6. On de-contestation, see Freeden (1996) and Norval (2000).

7. A few exceptions before that date are Thorstein 
Veblen (1915: 118, 128-29), Bernhard Stern (1937) and Joseph Schumpeter (1939: 289).

8. A type of argument first found in the report on science to the US President from Vannevar Bush, Director of the Office of Scientific Research and Development (Bush, 1945) - but without the word innovation -, and economic historian Rupert Maclaurin, secretary to one of the four committees that assisted Bush (Maclaurin, 1949).

9. One of the firsts, if not the first to talk of innovation in terms of "initiative" is Gabriel Tarde in Les lois de l'imitation (Tarde, 1890).

10. On counter-concepts, see Koselleck (1975).

11. "Les savants anglais auraient donc été plus souvent originaux et novateurs que les Allemands, car c'est surtout à cause de l'originalité des idées et des découvertes qu'un homme est élevé au titre d'Associé étranger dans une académie" [English scholars were therefore more often original and innovative than their German counterparts, because it is mainly due to the originality of ideas and to discoveries that one is promoted as a foreign associate within an academy] (Candolle, 1873 : 56).

12. Seventy years earlier, Tarde discussed imitation in similar terms: "le plus imitateur des hommes est novateur par quelque côté" [The most imitative man is to a certain extent a novator too] (Tarde, 1890: 46). 13. Or science or research; these terms are not always distinguished in the literature.

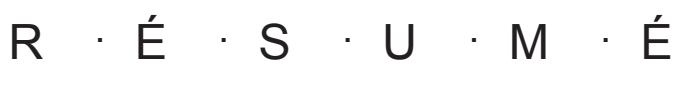

Innovation is a concept that everyone understands spontaneously - or thinks he understands -; that every theorist talks about and every government espouses. Yet, it has not always been so. For the last five hundred years, the concept innovation has been a dirty word.

The history of the concept of innovation is an untold story. It is a story of myths and conceptual confusions. In this paper, I study the ways in which thoughts on innovation of early-modern society gave rise to innovation theory in the twentieth century. Namely how, when and why a pejorative and morally connoted word shifted to a much valued concept. I offer a history of the concept of innovation, going back to Antiquity. A history that takes the use of the concept seriously: from polemical to instrumental to theoretical.

\section{Résumé \\ Pour une histoire du concept d'innovation : arme, instrument et cliché}

L'innovation est un concept que chacun d'entre nous comprend spontanément - ou croit comprendre -, qu'à peu près tout chercheur utilise dans ses travaux et que chaque gouvernement épouse quand vient le temps d'élaborer des politiques économiques. Il n'en a pas toujours été ainsi. Pendant plus de 500 ans, l'innovation était un concept contesté et, depuis la Réforme, essentiellement péjoratif.

L'historiographie du concept d'innovation reste à faire. Les rares et brèves réflexions sont actuellement empreintes de mythes et de confusions conceptuelles. La présente communication propose une historiographie documentant les usages du concept au fil des siècles : 
polémiques, instrumentaux et théoriques. Plus particulièrement, on discutera quand, comment et pourquoi le concept est devenu, et ce en moins d'un siècle, une valeur et un slogan. 